\title{
Agronomic performance of cowpea cultivars (Vigna unguiculata (L.) Walp) under application of limestone doses
}

\author{
Antônio Luís Galvão de Almeida ${ }^{1}$, Fábio Luiz Checchio Mingotte ${ }^{2 *} \oplus$, Anderson Prates Coelho ${ }^{2} \odot$, \\ Leandro Borges Lemos ${ }^{2} \odot$, Francisco de Brito Melo $^{3} \odot$, Renato de Mello Prado ${ }^{2} \odot$ \\ ${ }^{1}$ Instituto de Ensino Superior Múltiplo, Timon, MA, Brasil. E-mail: algalmeida@gmail.com \\ ${ }^{2}$ Universidade Estadual Paulista, Faculdade de Ciências Agrárias e Veterinárias, Jaboticabal, SP, Brasil. E-mail: flcmingotte@gmail.com; anderson_100ssp@hotmail.com; \\ leandro.lemos@unesp.br; rm.prado@unesp.br \\ ${ }^{3}$ Embrapa Meio Norte, Teresina, PI, Brasil. E-mail: francisco.brito@embrapa.br
}

ABSTRACT: Evaluating agricultural management practices, such as liming, is essential in regions with acidic soils to increase the yield of agricultural crops. The aim was to evaluate soil fertility, agronomic performance, and grain quality of cowpea cultivars under application of limestone doses. The experiment was carried out in Argissolo Vermelho Amarelo (Ultisol), with initial base saturation of $26 \%$, during two agricultural years. A randomized block design was used, in split plots, with four replications. The plots were composed of five limestone doses (0,1,2, 3 and 4 times the recommended rate to reach $50 \%$ base saturation), and the subplots were formed by two cowpea cultivars (BR 17 Gurgueia and BRS Guariba). The applied doses of limestone, with relative total neutralizing power (RTNP) of $91 \%$, were $0,1.3,2.6,3.9$ and $5.2 \mathrm{t} \mathrm{ha}^{-1}$. Liming increased soil fertility, increasing pH, calcium, magnesium, and base saturation, and decreasing soil acidity. Maximum grain yields were obtained with limestone doses between 3.1 and 3.2 t ha $^{-1}$ for the cultivar BR 17 Gurgueia and between 3.3 and 3.4 tha $^{-1}$ for the cultivar BRS Guariba, reaching average base saturation values of approximately 48 and $55 \%$, respectively.

Key words: grain yield; liming; soil acidity; yield components

\section{Desempenho agronômico de cultivares de feijão-caupi (Vigna unguiculata (L.) Walp) sob aplicação de doses de calcário}

RESUMO: A avaliação de manejos agrícolas, como a calagem, é essencial em regiões com solos ácidos para o incremento da produtividade das culturas agrícolas. Objetivou-se avaliar a fertilidade do solo, o desempenho agronômico e a qualidade dos grãos de cultivares de feijão-caupi sob aplicação de doses de calcário. O experimento foi conduzido em Argissolo Vermelho-Amarelo, com saturação por bases inicial de $26 \%$, durante dois anos agrícolas. Utilizou-se o delineamento de blocos casualizados, em parcelas subdivididas, com quatro repetições. As parcelas foram compostas por cinco doses de calcário $(0,1,2,3$ e 4 vezes a dose recomendada para atingir saturação por bases de 50\%), e as subparcelas formadas por duas cultivares de feijão-caupi (BR 17 Gurgueia e BRS Guariba). As doses de calcário aplicadas, com poder relativo e neutralização total (PRNT) de 91\%, foram de $0,1,3,2,6,3,9$ e 5,2 tha-1. A calagem aumentou a fertilidade do solo, proporcionando a elevação do pH, cálcio, magnésio e saturação por bases e diminuição da acidez do solo. Doses de calcário entre 3,1 e 3,2 t ha-1 promovem a máxima produtividade de grãos da cultivar BR 17 Gurgueia e entre 3,3 e 3,4 tha-1 na cultivar BRS Guariba, sendo atingido valores de saturação por base médios de aproximadamente 48 e $55 \%$, respectivamente.

Palavras-chave: produtividade de grãos; calagem; acidez do solo; componentes de produção

\footnotetext{
* Fábio Luiz Checchio Mingotte - E-mail: flcmingotte@gmail.com (Corresponding author)

Associate Editor: Adônis Moreira
} 


\section{Introduction}

Cowpea (Vigna unguiculata (L.) Walp) is native to the African continent, with Nigeria being the world's largest producer (FAOSTAT, 2020). It is a basic food for the population of several countries, being an important source of proteins, carbohydrates, and nutrients (Gondwe et al., 2019). In Brazil, despite the low average yield of around $475 \mathrm{~kg} \mathrm{ha}^{-1}$ (Conab, 2020), breeding programs have developed cultivars adapted to different climate and soil conditions, as well as to cultivation systems, with tolerance to biotic and abiotic stresses (Freire Filho et al., 2011).

However, due to the great sensitivity of cowpea to aluminum and manganese toxicity, the use of limestone is among the most economical and fundamental practices for obtaining high yields (Fernandes et al., 2013). Liming increases $\mathrm{pH}$ and eliminates exchangeable Al from the soil, besides providing nutrients such as $\mathrm{Ca}$ and $\mathrm{Mg}$, as well as the availability of macronutrients due to the neutralization of acidity, in addition to promoting greater growth of the root system because of the improvements in soil chemical conditions (Melo et al., 2005; Cravo et al., 2012).

Although the beneficial effects of liming on soil chemical attributes, as well as on the yield components and yield of legume species, such as common bean (Phaseolus vulgaris L.) (Silva et al., 2011) and soybean (Glycine max L.) (Bortoluzzi et al., 2014), are widely known, there are few reports in the scientific literature on its use in cowpea cultivation. For being considered a rustic and tolerant crop to various stresses, management practices such as fertilization, irrigation and liming are often neglected in its cultivation.

In a study conducted by Cravo et al. (2012), using limestone doses $\left(0,1,2,3\right.$ and $\left.4 \mathrm{t} \mathrm{ha}^{-1}\right)$ in systems with succession of maize, rice and cowpea crops in a medium-textured Latossolo Amarelo distrófico (Oxisol), the authors observed different responses as a function of cowpea cultivars. Thus, more studies are needed to guide producers and researchers in the definition of the ideal soil base saturation for cowpea cultivars, through the application of limestone.

The objective of this study was to evaluate soil fertility and the agronomic performance and grain quality of cowpea cultivars under the application of limestone doses.

\section{Materials and Methods}

The experiment was carried out in Teresina, PI, Brazil, near the coordinates of $05005^{\prime} 21^{\prime \prime} \mathrm{S}$ latitude, of $422^{\circ} 48^{\prime} 07^{\prime \prime}$ $\mathrm{W}$ longitude and average altitude of 74 meters. According to Köppen's classification, the climate is Aw, hot and humid with summer/autumn rains and rainfall ranging from $1,000 \mathrm{~mm}$ to $1,800 \mathrm{~mm}$ (Alvares et al., 2013). The soil of the experimental area is Argissolo Vermelho-Amarelo (Ultisol) (Embrapa, 2013) with sandy texture, containing $339 \mathrm{~g} \mathrm{~kg}^{-1}$ of coarse sand, 536.5 $\mathrm{g} \mathrm{kg}^{-1}$ of fine sand, $48.5 \mathrm{~g} \mathrm{~kg}^{-1}$ of silt and $76 \mathrm{~g} \mathrm{~kg}^{-1}$ of clay.

Before installing the experiment, soil samples were collected for fertility analysis in the $0.00-0.20 \mathrm{~m}$ layer, following the methodology of Raij et al. (2001). The values found in the soil chemical analysis were: $\mathrm{pH}\left(\mathrm{CaCl}_{2}\right)=4.2 ; \mathrm{OM}\left(\mathrm{g} \mathrm{dm}^{-3}\right)=$ 15; $\mathrm{P}$ resin $\left(\mathrm{mg} \mathrm{dm}^{-3}\right)=12 ; \mathrm{H}+\mathrm{Al}\left(\mathrm{cmol}_{\mathrm{c}} \mathrm{dm}^{-3}\right)=3.6 ; \mathrm{K}\left(\mathrm{cmol}_{c}\right.$ $\left.\mathrm{dm}^{-3}\right)=0.08 ; \mathrm{Ca}\left(\mathrm{cmol}_{\mathrm{c}} \mathrm{dm}^{-3}\right)=0.9 ; \mathrm{Mg}\left(\mathrm{cmol}_{\mathrm{c}} \mathrm{dm}^{-3}\right)=0.3 ; \mathrm{sum}$ of bases $\left(\mathrm{cmol}_{\mathrm{c}} \mathrm{dm}^{-3}\right)=1.28$; cation exchange capacity $\left(\mathrm{cmol}_{\mathrm{c}}\right.$ $\left.\mathrm{dm}^{-3}\right)=4.88$ and base saturation of $26 \%$.

The ideal minimum base saturation for cowpea is $60 \%$ (Melo \& Cardoso, 2017), calculated from the following equation (0.00-0.20 m layer) (Raij et al., 1997): $D=((V 2-V 1)$ $x$ CEC) / (RTNP)), in which $D$ represents the limestone dose in $\mathrm{t} \mathrm{ha}^{-1} ; \mathrm{V} 2$ is the recommended base saturation for cowpea (60\%); V1 is the actual base saturation of the soil; CEC is the cation exchange capacity of the soil, in $\mathrm{cmol}_{\mathrm{c}} \mathrm{dm}^{-3}$; and RTNP is the relative total neutralizing power of limestone. In the present experiment, V2 was adopted as equal to $50 \%$ and the other doses were multiples of the recommended dose to increase $\mathrm{V}$ to $50 \%$.

The limestone used was finely ground, with $\mathrm{CaO}=32 \%$, $\mathrm{MgO}=15 \%$, NP (Neutralizing Power) $=94.5 \%$, RE (Reactivity) $=96.30 \%$ and RTNP (Relative Total Neutralizing Power) $=91 \%$. Thus, the limestone dose calculated and used to increase base saturation to $50 \%$ was $1.30 \mathrm{t} \mathrm{ha}^{-1}$. Limestone was applied on January 15,2011 , followed by the pass of heavy and leveling harrow.

The experiment was installed in a randomized block design in split plots, with ten treatments and four replicates. The plots were represented by five doses of limestone $(0 ; 1.3$; 2.6; 3.9 and $5.2 \mathrm{t} \mathrm{ha}^{-1}$ ), corresponding to zero, one, two, three and four times the dose to increase base saturation to $50 \%$. The subplots were composed of two cowpea cultivars (BR 17 Gurgueia and BRS Guariba).

Each subplot was formed by five 10-m-long rows of cowpea plants, considering the three central rows as the useful area, disregarding 0.5 meters on each end (border). Cowpea seeds came from Embrapa Mid-North; the cultivar BR 17 Gurgueia has semi-prostrate plants and BRS Guariba has semi-erect plants.

Sowing was performed manually in holes, using five seeds per meter, on April 9, 2011 and April 6, 2012, and harvest was carried out on June 19 and 16 for both years of experiment.

Sowing fertilization, carried out in the sowing furrow, consisted of $60 \mathrm{~kg}$ of $\mathrm{P}_{2} \mathrm{O}_{5} \mathrm{ha}^{-1}$ and $50 \mathrm{~kg}$ of $\mathrm{K}_{2} \mathrm{O}$ ha-1 for the two agricultural years. In the two years, $20 \mathrm{~kg} \mathrm{ha}^{-1}$ of $\mathrm{N}$ were also applied as top-dressing, in the form of urea, in the phenological stage $V_{3}$ (beginning of development of the third trifoliate leaf), following the recommendations of Melo et al. (2005).

Cowpea crop was maintained under rainfed conditions, and the data of rainfall and maximum and minimum temperatures recorded along the growing period, in the years 2011 and 2012, are presented in Figure 1. 

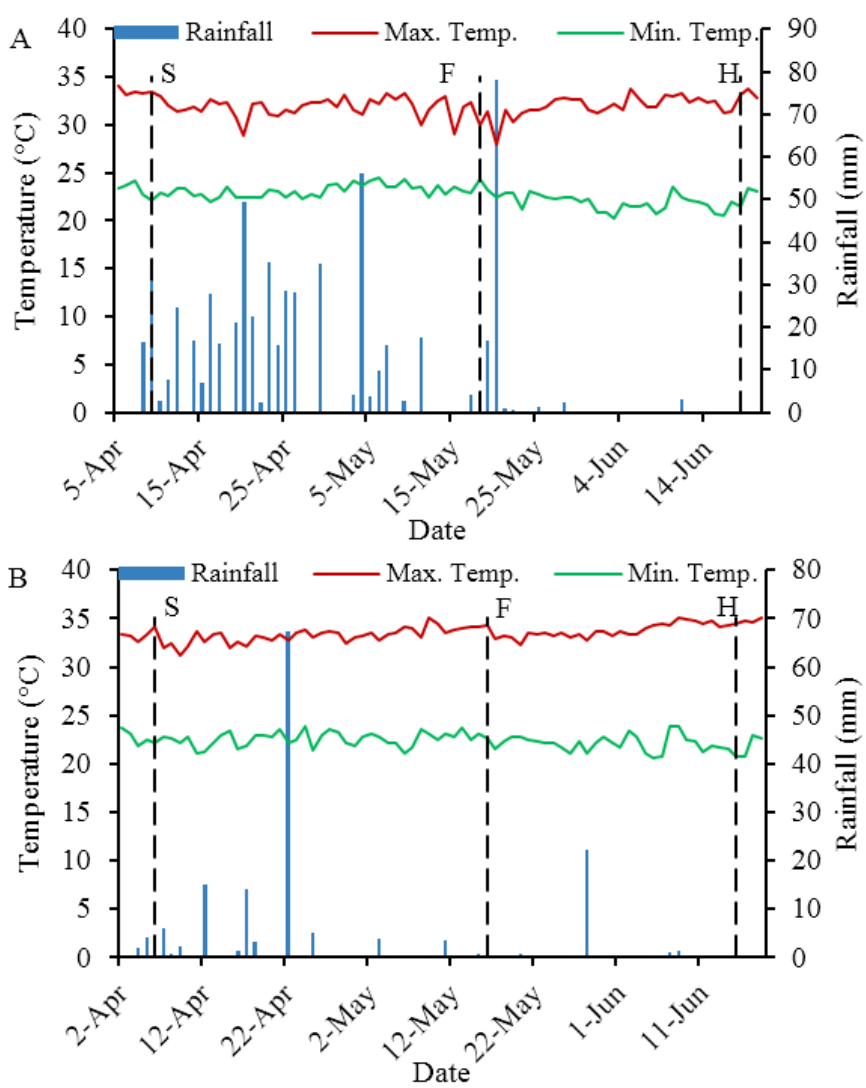

Figure 1. Rainfall and maximum and minimum daily temperatures during the experimental period in the agricultural years of 2011 (A) and 2012 (B), in Teresina-PI. Year 2011: sowing on April 9, flowering on May 19 and harvest on June 19. Year 2012: sowing on April 6, flowering on May 16 and harvest on June 16. S: sowing; F: flowering; H: Harvest

The maximum and minimum average temperatures in 2011 were 32.0 and $22.7^{\circ} \mathrm{C}$, respectively, with accumulated rainfall of $604 \mathrm{~mm}$. In 2012, the maximum and minimum average temperatures were 33.5 and $22.3^{\circ} \mathrm{C}$, respectively, with accumulated rainfall of $155 \mathrm{~mm}$. Invasive plants were controlled by manual weeding, with no need for applying phytosanitary products to control pest insects and diseases.

Harvest was carried out by uprooting and manual threshing when plants had defoliated stems and $90 \%$ of dried pods $\left(R_{5}\right)$. Before harvest, the final population of plants was determined in the three cultivation rows of the useful area of the subplot, obtaining average values of 64,000 and 68,000 plants ha $^{-1}$ in 2011 and 2012, respectively for the two cultivars.

At five (5) and seventeen (17) months after limestone application, four (4) single soil samples were collected to form one composite sample in the $0.00-0.20 \mathrm{~m}$ layer in each subplot to determine the chemical attributes, according to the method described by Raij et al. (2001). Ten consecutive plants were collected in the cultivation row of each subplot to determine the number of pods per plant, number of grains per pod and 100 -grain weight. Pod yield was obtained by weighing the pods present in the two useful rows, with values extrapolated for $\mathrm{kg} \mathrm{ha}^{-1}$ and moisture standardized to $13 \%$ (wet basis). Grain yield was obtained after harvesting two central rows of each subplot, by summing the amount of grains produced by the 10 plants previously collected to account for the yield components, with determination of the moisture content of the grains, standardized to $13 \%$ (wet basis).

The crude protein content $\left(\mathrm{g} \mathrm{kg}^{-1}\right)$ of the grains was calculated by the equation CPC = Total N $\times 6.25$ (AOAC, 1995), in which Total $\mathrm{N}$ represents the total $\mathrm{N}$ content in the grains, obtained by sulfuric acid digestion (Bataglia et al., 1983). Cooking time was obtained using the adapted Mattson cooker, which consists of 25 vertical plungers, weighing $90 \mathrm{~g}$ at the end, with a $1 / 16$ " tip. The tip rests on the beans during cooking and, when the grain is cooked, the tip penetrates it, displacing the plunger. The time to cook the sample was obtained when $50 \%+1$ of the plungers, that is, 13 plungers, were displaced. To perform this evaluation, the grains were previously hydrated in distilled water for a period of 12 hours. During the test, water temperature was maintained at $96^{\circ} \mathrm{C}$ (Silva et al., 2011).

The results were subjected to analysis of variance by $\mathrm{F}$ test and the means were compared by Tukey test at $5 \%$ probability level. When the factors limestone doses or the Doses versus Cultivars interaction were significant, polynomial regression analysis was performed. For the yield components (number of pods per plant, number of grains per pod and 100-grain weight), the study of Pearson's simple correlation ( $r$ ) was performed, considering yield as a dependent factor, and the values obtained were subjected to the t-test at $5 \%$ probability level. Statistical analyses were performed using Sisvar software (Ferreira, 2011).

\section{Results and Discussion}

There was no significant response to the interaction between limestone doses and cowpea cultivars for all variables studied. Exception for potassium (K) and cation exchange capacity (CEC), limestone doses significantly interfered in all soil chemical attributes evaluated (Table 1).

Limestone doses increased the values of $\mathrm{pH}, \mathrm{P}, \mathrm{Ca}, \mathrm{Mg}$ and base saturation (V\%), while for soil acidity ( $\mathrm{H}+\mathrm{Al}$ ) the increase of limestone doses reduced the values. Organic matter was not affected by limestone doses, showing an average value of $15 \mathrm{~g} \mathrm{dm}^{-3}$. Limestone application caused increments, with linear fits, in the $\mathrm{pH}$ value for the year 2011 and in $\mathrm{Ca}$ and $\mathrm{Mg}$ contents for both years (Figure 2). The increment in the base contents of the soil increased its base saturation, both in the first and second agricultural year. In the first year, five (5) months after limestone application, the maximum soil base saturation was $55 \%$. This means that limestone improved soil chemical attributes, providing cations and reducing acidity, hence improving soil fertility. In addition to cations, the limestone doses increased the $\mathrm{P}$ available in the soil, and the increment was linear for the year 2011 and quadratic for 2012. This difference in the models fitted to $P$ content data can be explained by the difference in the absorption of this nutrient as a function of the limestone dose applied. As the increase in limestone doses caused a linear increase in $\mathrm{P}$ 
Table 1. Chemical attributes of the Argissolo Vermelho-Amarelo (Ultisol) at 5 and 17 months after application of limestone doses $\left(0 ; 1.3 ; 2.6 ; 3.9\right.$ and $\left.5.2 \mathrm{t} \mathrm{ha}^{-1}\right)$. Teresina- $\mathrm{PI}^{1}$

\begin{tabular}{|c|c|c|c|c|c|c|c|c|}
\hline \multirow{2}{*}{ Treatments } & \multirow{2}{*}{$\underset{\left(\mathrm{CaCl}_{2}\right)}{\mathbf{p H}}$} & \multirow{2}{*}{$\begin{array}{c}P(\text { resin }) \\
\left(\mathrm{mg} \mathrm{dm}^{-3}\right)\end{array}$} & $\mathrm{H}+\mathrm{Al}$ & $\mathbf{K}$ & $\mathrm{Ca}$ & Mg & CEC & V \\
\hline & & & \multicolumn{5}{|c|}{$\left(\mathrm{cmol}_{\mathrm{c}} \mathrm{dm}^{-3}\right)$} & (\%) \\
\hline & \multicolumn{8}{|c|}{2011 - 5 months after application } \\
\hline \multicolumn{9}{|c|}{ Limestone doses (D) } \\
\hline 1.3 & $4.6 b$ & $6.7 a b$ & $3.3 a b$ & 0.06 & $1.2 b$ & $0.6 b c$ & 5.1 & $35.8 \mathrm{bc}$ \\
\hline 2.6 & $4.9 a b$ & 7.7ab & $2.7 a b$ & 0.05 & $1.4 a b$ & $1.0 \mathrm{ab}$ & 5.1 & $47.3 a b$ \\
\hline CV (\%) & 3.0 & 19.3 & 14.7 & 15.3 & 21.1 & 28.3 & 10.2 & 17.5 \\
\hline$F$ test $(D)$ & $27.4^{* *}$ & $5.3^{*}$ & $5.2^{*}$ & $1.4^{\mathrm{ns}}$ & $5.6 * *$ & $11 * *$ & $1.1^{\text {ns }}$ & $10.6 * *$ \\
\hline & \multicolumn{8}{|c|}{2012 - 17 months after application } \\
\hline \multicolumn{9}{|c|}{ Limestone doses (D) } \\
\hline 0 & $4.4 d$ & $7.0 \mathrm{~b}$ & $3.1 \mathrm{a}$ & 0.08 & $0.7 c$ & $0.3 d$ & 4.2 & $25.8 \mathrm{c}$ \\
\hline 1.3 & $4.8 c$ & $7.3 b$ & $2.4 a b$ & 0.09 & $1.1 \mathrm{bc}$ & $0.6 \mathrm{~cd}$ & 4.1 & $42.8 b$ \\
\hline CV (\%) & 2.2 & 28.8 & 19.1 & 13.2 & 18.7 & 17.8 & 11.6 & 13.8 \\
\hline $\mathrm{F}$ test $(\mathrm{D})$ & $58.5^{* *}$ & $6.4 * *$ & $6.4 * *$ & $2.7^{\mathrm{ns}}$ & $11.4^{* *}$ & $28 * *$ & $1.8^{\mathrm{ns}}$ & $19.5^{* *}$ \\
\hline
\end{tabular}

${ }^{1}$ Means followed by the same lowercase letter in the column do not differ from each other by Tukey test at $5 \%$ significance level. ${ }^{* *}$ significant at $1 \%$ and ${ }^{n}$ not significant by $\mathrm{F}$ test, respectively.
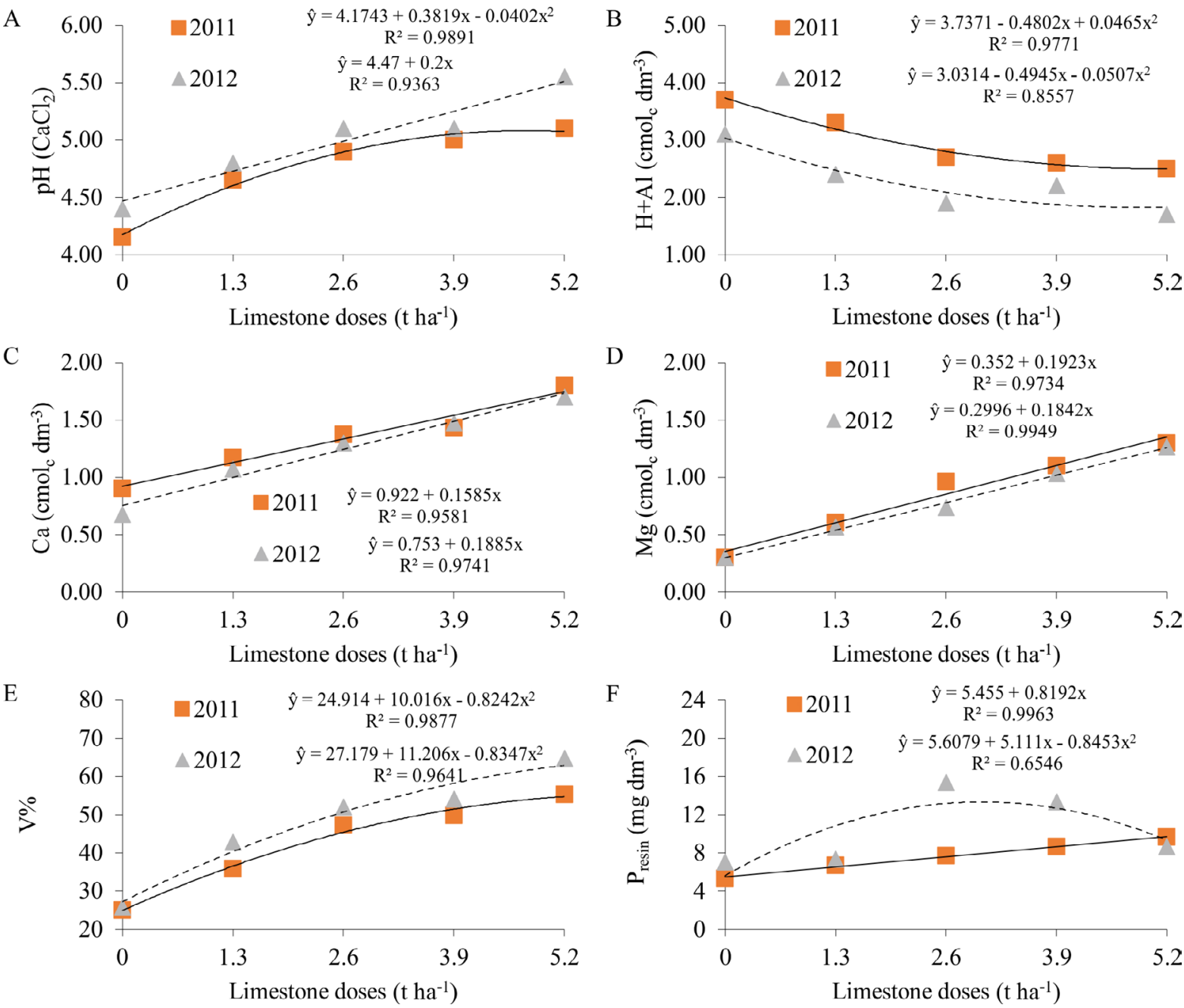

Figure 2. Regression models fitted to the data of the variables $\mathrm{pH}(\mathrm{A})$, potential acidity $(\mathrm{H}+\mathrm{Al}-\mathrm{B}), \mathrm{Ca}(\mathrm{C}), \mathrm{Mg}$ content (D), base saturation (V\% - E) and P (F) content of the soil submitted to limestone doses, in two years of cultivation (2011 and 2012), in Teresina-PI 
availability in the first year, the absorption of $\mathrm{P}$ by plants at these doses was higher compared to its absorption at lower doses, justifying the reduction in $\mathrm{P}$ availability at the highest doses in the second year.

For the organic matter (OM) content, it was observed that in the first agricultural year, after limestone application, the OM content decreased up to the limestone dose of $1.7 \mathrm{t} \mathrm{ha}^{-1}$, with an increment after this value (Figure 3 ). In the second agricultural year, an increase in OM content was obtained with the increase of limestone doses, up to a maximum of $3.8 \mathrm{t} \mathrm{ha}^{-1}$. These differences in the variation of OM content between years are due to the dynamics promoted by the application of limestone in the soil. Initially, by increasing the $\mathrm{pH}$ of very acidic soils, as that of the present study (Figure 2 ), the application of limestone creates a more favorable environment for the increase in the microbiological activity of the soil, oxidizing the OM (Raij et al., 2011). Later, over the years, the reduction of soil acidity promotes greater plant growth and, consequently, higher total biomass that will be transformed into OM in the soil, increasing its content.

The increase in soil fertility due to limestone doses directly interfered with the yield components of the cowpea cultivars

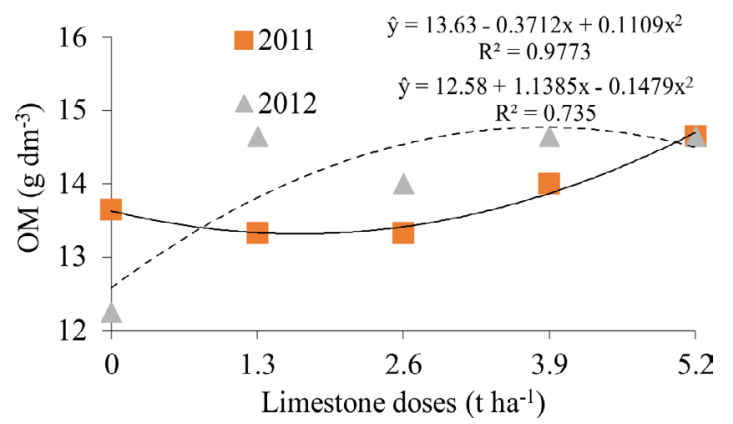

Figure 3. Regression models fitted to soil organic matter data under limestone doses in the two agricultural years.
(Table 2). For the number of pods per plant (NPP) in the two agricultural years evaluated and for the 100-grain weight (100GW) in 2012, there were significant differences caused by the limestone doses. There was a significant effect for the cultivar factor on all variables in the two agricultural years evaluated. The cultivar BR 17 Gurgueia had the highest values of NPP and NGP in the two agricultural years, while the cultivar BRS Guariba had the highest values of $100 \mathrm{GW}$. The interaction between limestone doses versus cultivar was not significant for the variables studied in the two agricultural years.

It was observed that the increase of NPP as a function of limestone doses was quadratic in the two agricultural years and for the two cultivars (Figure 4). The maximum values of NPP for the cultivars BR 17 Gurgueia (12.0 and 13.3) and BRS Guariba (10.7 and 10.0) were obtained with the limestone doses of $2.7 \mathrm{tha}^{-1}$ and $3.0 \mathrm{tha}^{-1}$, respectively, for 2011, and 2.9 t ha ${ }^{-1}$ and 2.9 t ha $^{-1}$, respectively, for the 2012 agricultural year.

In general, the increase in soil fertility due to the application of limestone increased pod yield (PY) and grain yield (GY) of the cowpea cultivars, and the same fact was observed for the yield components (Table 3). For the first agricultural year, PY and GY did not differ between limestone doses, whereas in the agricultural year 2012 limestone doses directly interfered in PY and GY. For cultivars, differences were observed for the two agricultural years, both for PY and GY, with the genotype BR 17 Gurgueia showing the highest yields. There was no significant response to the interaction between limestone doses and cultivars, in any of the two agricultural years, for all response variables evaluated.

Quadratic increases were observed in the PY and GY of the cowpea cultivars as a function of limestone doses in the two agricultural years (Figure 5). The maximum values of PY $\left(1,400\right.$ and 1,407 $\left.\mathrm{kg} \mathrm{ha}^{-1}\right)$ and GY (1,092 and 1,100 kg ha-1) of BR 17 Gurgueia for the first and second year were reached

Table 2. Number of pods per plant (NPP), number of grains per pod (NGP) and 100-grain weight of the two cowpea cultivars (BR 17 Gurgueia and BRS Guariba) subjected to limestone doses $\left(0 ; 1.2 ; 2.6 ; 3.9\right.$ and 5.3 t ha $^{-1}$ ) in two agricultural years (2011 and 2012), Teresina-PI ${ }^{1}$

\begin{tabular}{|c|c|c|c|c|c|c|}
\hline \multirow{3}{*}{ Treatments } & \multicolumn{2}{|c|}{ NPP } & \multicolumn{2}{|c|}{ NGP } & \multicolumn{2}{|c|}{$100 \mathrm{GW}$} \\
\hline & 2011 & 2012 & 2011 & 2012 & 2011 & 2012 \\
\hline & \multicolumn{4}{|c|}{-------- no --------- } & \multicolumn{2}{|c|}{--------- g --------- } \\
\hline \multicolumn{7}{|l|}{ Limestone doses (D) } \\
\hline 0 & 10.1 & 9.1 & 11.7 & 11.6 & 17.1 & 16.6 \\
\hline 1.3 & 10.7 & 10.1 & 11.6 & 12.1 & 17.7 & 17.3 \\
\hline 2.6 & 11.5 & 12.5 & 11.9 & 12.5 & 17.5 & 17.4 \\
\hline 3.9 & 11.0 & 10.9 & 12.1 & 12.0 & 17.3 & 16.9 \\
\hline 5.2 & 10.2 & 10.1 & 11.2 & 11.5 & 17.2 & 16.7 \\
\hline CV (\%) & 8.1 & 8.3 & 6.6 & 9.8 & 4.1 & 2.9 \\
\hline \multicolumn{7}{|l|}{ Cultivars (C) } \\
\hline BR 17 Gurgueia & $11.4 \mathrm{a}$ & $12.2 \mathrm{a}$ & $13.3 \mathrm{a}$ & $13.7 \mathrm{a}$ & $14.2 \mathrm{~b}$ & $14.2 \mathrm{~b}$ \\
\hline BRS Guariba & $10.0 \mathrm{~b}$ & $8.9 b$ & $10.1 \mathrm{~b}$ & $10.1 \mathrm{~b}$ & $20.5 \mathrm{a}$ & $19.7 \mathrm{a}$ \\
\hline CV (\%) & 16.0 & 9.1 & 7.3 & 5.6 & 3.9 & 3.3 \\
\hline \multicolumn{7}{|l|}{ F test } \\
\hline D & $3.33^{*}$ & $16.43^{* *}$ & $1.39^{\text {ns }}$ & $0.93^{\text {ns }}$ & $0.96^{\mathrm{ns}}$ & $4.01^{*}$ \\
\hline $\mathrm{C}$ & $7.11^{*}$ & $116.68 * *$ & $142.42^{* *}$ & $288.00 * *$ & $853.40 * *$ & $955.42 * *$ \\
\hline$D \times C$ & $0.26^{\text {ns }}$ & $0.56^{\text {ns }}$ & $0.59^{\text {ns }}$ & $0.36^{\text {ns }}$ & $0.28^{\text {ns }}$ & $0.45^{\text {ns }}$ \\
\hline
\end{tabular}

${ }^{1}$ Means followed by the same lowercase letter in the column do not differ from each other by Tukey test at $5 \%$ significance level. ${ }^{* *}$ significant at $1 \%$ and ${ }^{\text {ns }}$ not significant by $\mathrm{F}$ test, respectively 

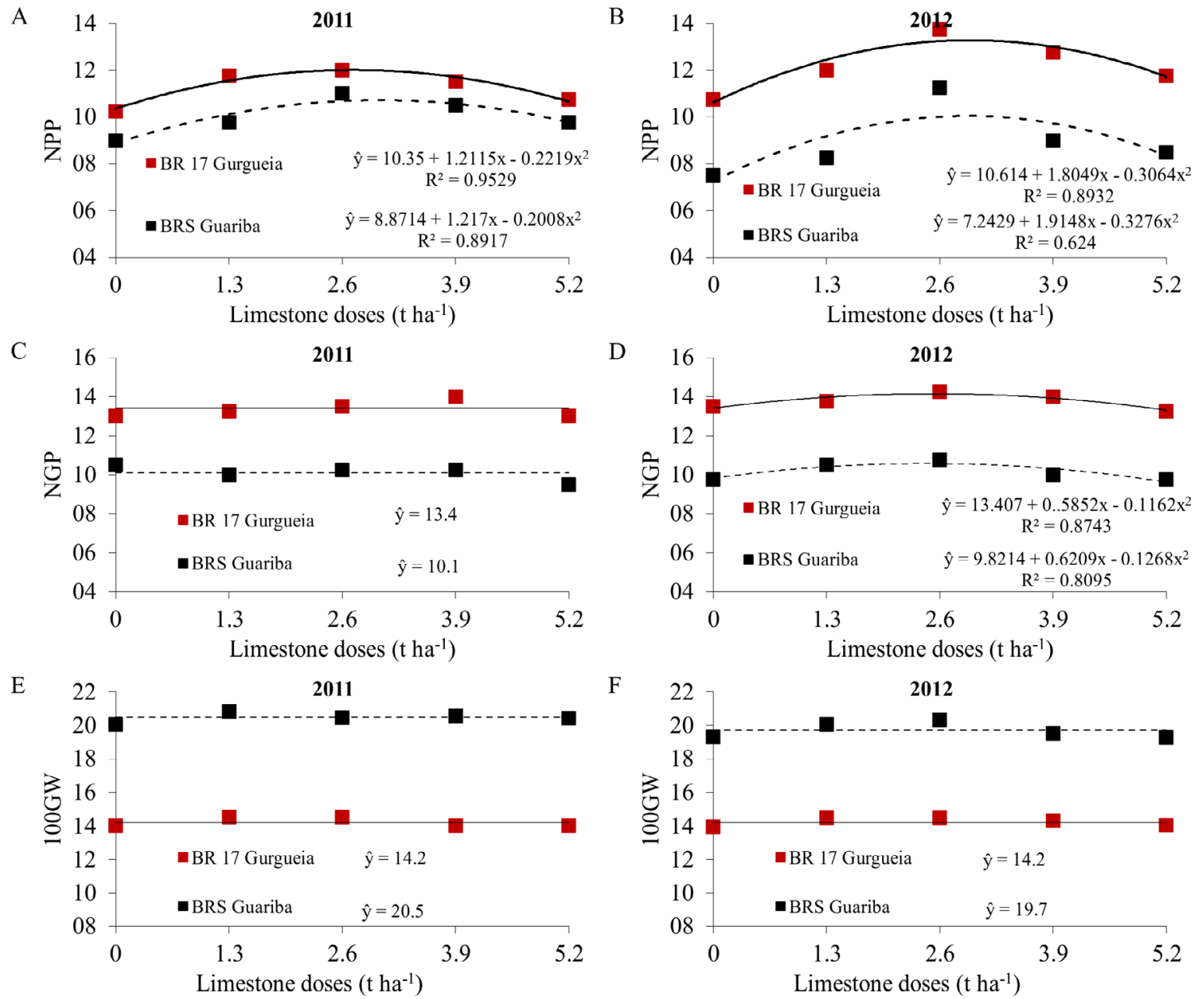

Figure 4. Regression models adjusted to the data of the number of pods per plant $(A$ and $B)$, number of grains per pod ( $C$ and D) and 100-grain weight (E and F) of two cowpea cultivars (BR 17 Gurgueia and BRS Guariba) as a function of limestone doses, in two years of cultivation (2011 and 2012), in Teresina-PI.

Table 3. Pod yield (PY) and grain yield (GY) of the two cowpea cultivars (BR 17 Gurgueia and BRS Guariba) subjected to limestone doses $\left(0 ; 1.2 ; 2.6 ; 3.9\right.$ and $\left.5.3 \mathrm{t} \mathrm{ha}^{-1}\right)$ in two agricultural years (2011 and 2012), Teresina-PI ${ }^{1}$.

\begin{tabular}{|c|c|c|c|c|}
\hline \multirow{3}{*}{ Treatments } & \multicolumn{2}{|c|}{ PY } & \multicolumn{2}{|c|}{ GY } \\
\hline & 2011 & 2012 & 2011 & 2012 \\
\hline & \multicolumn{4}{|c|}{ 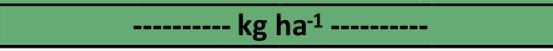 } \\
\hline \multicolumn{5}{|l|}{ Limestone doses (D) } \\
\hline 0 & 1049.6 & 889.9 & 653 & 598 \\
\hline 1.3 & 1124.2 & 1013.7 & 759 & 725 \\
\hline 2.6 & 1254.5 & 1366.7 & 952 & 1056 \\
\hline 3.9 & 1176.1 & 1115.1 & 926 & 898 \\
\hline 5.2 & 1115.0 & 1109.7 & 800 & 807 \\
\hline CV (\%) & 17.5 & 15.6 & 24.9 & 15.6 \\
\hline \multicolumn{5}{|l|}{ Cultivars (C) } \\
\hline BR 17 Gurgueia & $1264.6 \mathrm{a}$ & $1253.9 \mathrm{a}$ & $942 \mathrm{a}$ & 943 a \\
\hline BRS Guariba & $1023.1 \mathrm{~b}$ & $944.1 \mathrm{~b}$ & $694 \mathrm{~b}$ & $691 b$ \\
\hline CV (\%) & 7.0 & 19.8 & 6.6 & 21.1 \\
\hline \multicolumn{5}{|l|}{$\mathrm{F}$ test } \\
\hline D & $1.16^{\mathrm{ns}}$ & $8.08^{* *}$ & $2.91^{\mathrm{ns}}$ & $15.11^{* *}$ \\
\hline $\mathrm{C}$ & $91.27 * *$ & $20.31 * *$ & $208.79 * *$ & $21.46^{* *}$ \\
\hline $\mathrm{D} \times \mathrm{C}$ & $1.76^{\mathrm{ns}}$ & $0.29^{\text {ns }}$ & $1.16^{\mathrm{ns}}$ & $0.32^{\text {ns }}$ \\
\hline
\end{tabular}

${ }^{1}$ Means followed by the same lowercase letter in the column do not differ from each other by Tukey test at $5 \%$ significance level. ${ }^{* *}$ significant at $1 \%$ and ${ }^{\text {ns }}$ not significant by F test, respectively. with limestone doses of 2.8 and $3.0 \mathrm{t} \mathrm{ha}^{-1}$ and 3.2 and $3.1 \mathrm{t}$ $\mathrm{ha}^{-1}$, respectively. For the cultivar BRS Guariba, the maximum values of PY (1,107 and 1,076 kg ha-1) and GY (792 and 827 $\mathrm{kg} \mathrm{ha}^{-1}$ ) for the first and second year were reached with limestone doses of 3.7 and $3.9 \mathrm{t} \mathrm{ha}^{-1}$ and 3.3 and $3.4 \mathrm{t} \mathrm{ha}^{-1}$, respectively. Thus, the cultivar BRS Guariba had its maximum yield at a limestone dose higher than that for the cultivar BR 17 Gurgueia. This indicates that, in addition to having lower yield, BRS Guariba is more demanding in terms of fertility than BR 17 Gurgueia (Figure 5). As a general average, the ideal doses of limestone for the cultivars BR 17 Gurgueia and BRS Guariba to obtain maximum yields were 3.0 and $3.6 \mathrm{t} \mathrm{ha}^{-1}$, being doses calculated to increase the $\mathrm{V} \%$ of the soil to 82 and $93 \%$, respectively.

The production component that had the highest correlation with GY was the NPP for the two cultivars, being significant at $5 \%$ probability level (Table 4). $100 \mathrm{GW}$ was significantly affected only in the second agricultural year, for the two cultivars. Thus, it was observed that the greatest explanation for the variability in the yield of the cultivars as a function of the application of limestone doses is due to the increase in NPP, followed by $100 \mathrm{GW}$. 

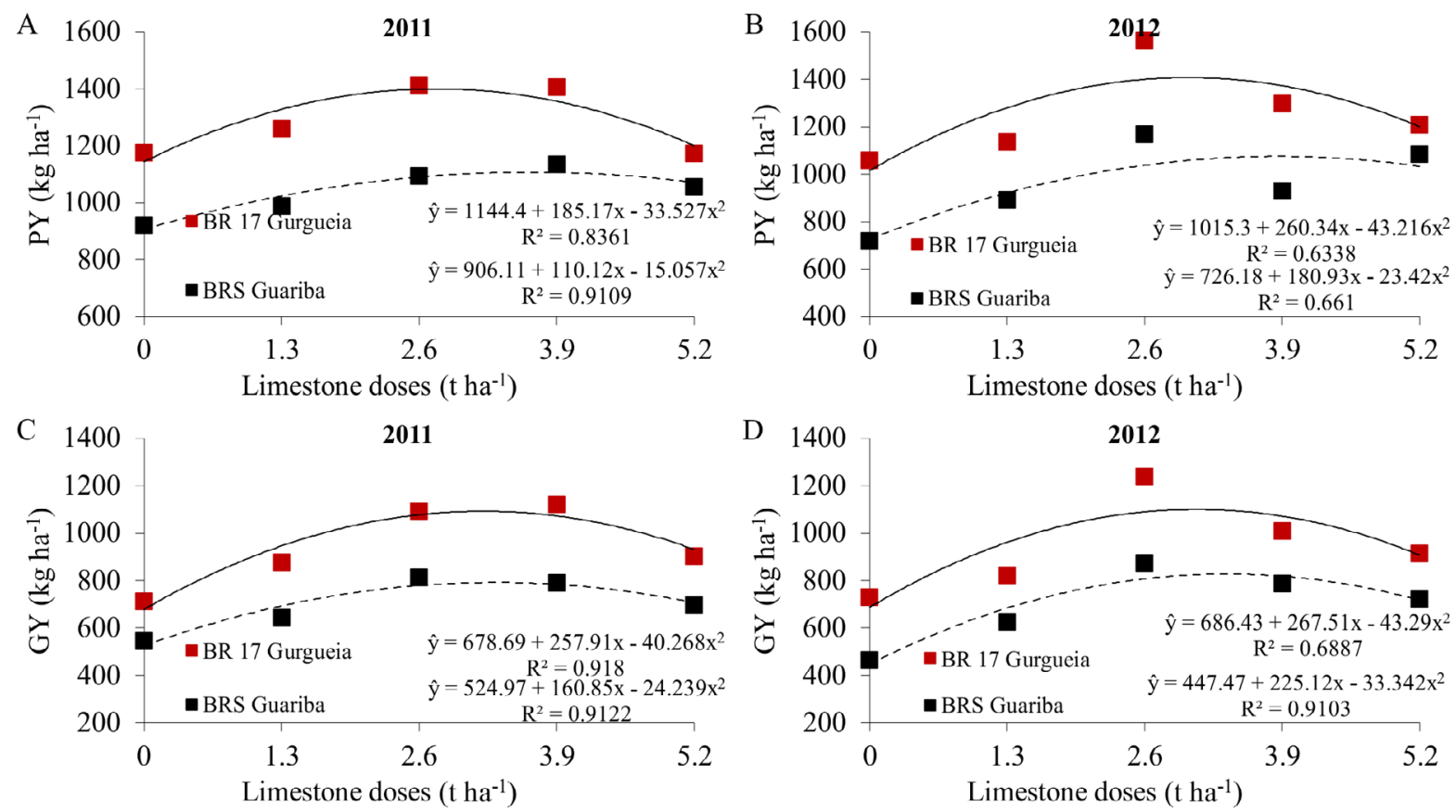

Figure 5. Regression models fitted to the data of pod yield (PY - A and B), grain yield (GY $-C$ and $D$ ) and harvest index of two cowpea cultivars (BR 17 Gurgueia and BRS Guariba) as a function of limestone doses, in two years of cultivation (2011 and 2012), in Teresina-PI.

Table 4. Simple Pearson's correlation coefficients ( $r$ ) between the mean values of the yield components (number of pods per plant, number of grains per pod and 100-grain weight) and grain yield (dependent variable) of two cowpea cultivars (BR 17 Gurgueia and BRS Guariba) subjected to limestone doses $\left(0 ; 1.2 ; 2.6 ; 3.9\right.$ and $\left.5.2 \mathrm{t} \mathrm{ha}^{-1}\right)$, in two years of cultivation (2011 and 2012), in Teresina-PI ${ }^{(1)}$

\begin{tabular}{ccccc}
\hline Cultivar & Year & NPP & NGP & $100 G W$ \\
\hline BR17 & 2011 & $0.44^{*}$ & $0.35^{\text {ns }}$ & $-0.01^{\text {ns }}$ \\
Gurgueia & 2012 & $0.60^{* *}$ & $0.32^{\text {ns }}$ & $0.47^{*}$ \\
BRS & 2011 & $0.75^{* *}$ & $0.26^{\text {ns }}$ & $0.11^{\text {ns }}$ \\
Guariba & 2012 & $0.77^{* *}$ & $0.15^{\text {ns }}$ & $0.42^{*}$ \\
\hline
\end{tabular}

As for the variables related to the technological quality of the grains, a small variability was observed for the factors cultivar and limestone doses, as well as the interaction between them (Table 5). Only for the crude protein content of the grains in the first agricultural year there were significant differences caused by the cultivar factor, with genotype BR 17 Gurgueia having the highest value.

The decrease in soil acidity with the increase of limestone doses is explained by the reaction of $\mathrm{OH}^{-}$, released by the corrective in the soil solution, with the $\mathrm{H}^{+}$of the solution (Raij, 2011). Thus, the amount of $\mathrm{H}^{+}$in the soil solution decreases and the $\mathrm{H}^{+}$adsorbed to the soil is released into the solution. With the release of the negative charges of the solid phase of the soil (CEC) that were bound to $\mathrm{H}^{+}$, the exchangeable bases move from the solution to the solid phase of the soil. This occurs because, with the addition of limestone, a large amount of $\mathrm{Ca}$ and $\mathrm{Mg}$ is added to the soil, leaving the solution with high concentrations of these bases. This fact generates
Table 5. Crude protein content and cooking time of the grains of two cowpea cultivars (BR 17 Gurgueia and BRS Guariba) subjected to limestone doses $\left(0 ; 1.2 ; 2.6 ; 3.9\right.$ and $\left.5.3 \mathrm{t} \mathrm{ha}^{-1}\right)$ in two agricultural years (2011 and 2012), Teresina- $\mathrm{PI}^{1}$

\begin{tabular}{|c|c|c|c|c|}
\hline \multirow{3}{*}{ Treatments } & \multicolumn{2}{|c|}{$\begin{array}{c}\text { Crude protein } \\
\text { content }\end{array}$} & \multicolumn{2}{|c|}{$\begin{array}{c}\text { Cooking } \\
\text { time }\end{array}$} \\
\hline & 2011 & 2012 & 2011 & 2012 \\
\hline & \multicolumn{2}{|c|}{----- g kg $^{-1}$-.--- } & \multicolumn{2}{|c|}{--- minutes --- } \\
\hline \multicolumn{5}{|c|}{ Limestone doses (D) } \\
\hline 0 & 254.3 & 205.6 & 20 & 11 \\
\hline 1.3 & 246.6 & 218.7 & 22 & 14 \\
\hline 2.6 & 252.3 & 230.8 & 20 & 12 \\
\hline 3.9 & 252.7 & 232.4 & 20 & 14 \\
\hline 5.2 & 252.1 & 237.9 & 20 & 14 \\
\hline CV (\%) & 8.8 & 12.2 & 29.2 & 23.6 \\
\hline
\end{tabular}

Cultivars (C)

\begin{tabular}{ccccc}
\hline BR 17 Gurgueia & 262.6 a & 231.0 & 20 & 12 \\
BRS Guariba & $240.6 \mathrm{~b}$ & 219.2 & 21 & 13 \\
CV (\%) & 6.3 & 10.6 & 26.3 & 22.6 \\
F test & & & & \\
D & $0.14^{\text {ns }}$ & $1.76^{\text {ns }}$ & $0.16^{\text {ns }}$ & $1.75^{\text {ns }}$ \\
C & $19.14^{* *}$ & $2.43^{\text {ns }}$ & $0.23^{\text {s }}$ & $0.48^{\text {ns }}$ \\
D XC & $2.84^{\text {ns }}$ & $1.96^{\text {ns }}$ & $0.49^{\text {ns }}$ & $0.98^{\text {ns }}$ \\
\hline
\end{tabular}

${ }^{1}$ Means followed by the same lowercase letter in the column do not differ from each other by Tukey test at $5 \%$ significance level. ${ }^{* *}$ significant at $1 \%$ and ${ }^{\text {ns }}$ not significant by F test, respectively.

an imbalance between the solid phase and the soil solution and, with the release of the $\mathrm{H}^{+}$adsorbed, the exchangeable bases move to the spaces that were previously occupied by $\mathrm{H}^{+}$ in the solid phase, increasing their total contents in the soil. As an indirect effect of the reduction in soil acidity, the available $\mathrm{P}$ content increases. This occurs because, with the increase in $\mathrm{pH}$ and reduction of soil acidity, less positive charges are available for binding to the available $\mathrm{P}$ in the form of $\mathrm{H}_{2} \mathrm{PO}_{4}$ 
and $\mathrm{H}_{2} \mathrm{PO}_{4}^{-2}$ and thus higher $\mathrm{P}$ content is available for plants (Buni, 2014).

Fernandes et al. (2013) evaluated the effects of the application of two doses of limestone on the chemical attributes of a soil cultivated with cowpea and observed that, with the increase in limestone dose, soil acidity decreased, and the available phosphorus content increased, as observed in the present study. In addition to improving soil fertility, with the reduction of acidity and increase in contents of exchangeable bases, liming can promote an increase in the organic carbon content of the soil over time.

It was observed that base saturation (V\%) was slightly higher in the second agricultural year, 17 months after limestone application, especially in the managements with higher doses of limestone. This probably occurred due to the residual effect of limestone. In the first year, fertility was evaluated five (5) months after limestone application and, in the managements with higher doses ( 3.9 and $5.2 \mathrm{t} \mathrm{ha}^{-1}$ ), probably part of the limestone applied did not react with the soil. Thus, these managements had higher base saturation 17 months after limestone application.

In addition, it was observed that limestone doses above zero did not increase soil base saturation to the calculated values of $50 \%, 74 \%, 98 \%$ and more than $100 \%$, respectively. The maximum base saturation obtained five (5) months after corrective application was 55\%. Soratto \& Crusciol (2008), evaluating the effects of limestone doses on soil fertility, also observed that the calculated limestone doses did not reach the desired level of soil base saturation. For the present study, this fact can be explained by the low natural fertility of the soil, with very low $\mathrm{Ca}$ and $\mathrm{Mg}$ contents. In the treatments with higher doses of limestone, the contents of $\mathrm{Ca}$ and $\mathrm{Mg}$ increased and consequently caused greater growth of cowpea plants and, as a result, greater nutrient extraction. Thus, at the end of the cycle part of $\mathrm{Ca}$ and $\mathrm{Mg}$ was extracted by the crop, decreasing the sum of bases of the soil and its base saturation in comparison to the value calculated to be reached.

Paradelo et al. (2015), conducting a review of long-term experiments with limestone application in acid soils, observed that initially the application of limestone can promote a reduction in soil organic matter content, due to the greater mineralization of organic matter with increase of soil $\mathrm{pH}$ to close to neutrality (Raij, 2011). However, over time and with constant applications of limestone, the organic matter content in the soil tends to increase, due to the increase in yield and dry matter of plants because, after harvest, there is a greater amount of crop residues on the soil. This fact was observed in the present study; in the first year, after the harvest of cowpea, the soil organic matter content was reduced in comparison to the zero dose (Figure 3). In the second year, evaluating the residual effect of the application, there was an increase in organic matter values due to the application of limestone, which is explained by the higher PY and GY of the treatments with limestone application (Figure 5). Even if the application of limestone promotes higher yield and, consequently, greater export of soil nutrients by crops, it is verified over time that the benefits of limestone application on the increase in soil fertility are greater than the removal of nutrients by grain harvesting (Raij et al., 2011; Paradelo et al., 2015).

The increase in the PY and GY of the cowpea cultivars as a result of the increase in limestone doses can be explained by the production component NPP. This occurs because, among the three yield components of cowpea (NPP, NGP and $100 \mathrm{GW}), \mathrm{NPP}$ is the most altered by agricultural management (Sokoto \& Singh, 2008; Kyei-Boahen et al., 2017). NGP shows high genotypic variability and, hence, is little influenced by agricultural managements (Locatelli et al., 2014; Tagliaferre et al., 2013). 100GW is mainly affected in studies on irrigation depths (Oliveira et al., 2011) and, since in the present study all treatments had the same availability of water from rainfall, this component contributed little to the increase in the yield of the cowpea cultivars.

Sokoto \& Singh (2008), evaluating the effect of phosphate rock doses on the improvement of soil fertility and, consequently, on the agronomic performance of cowpea, observed that the increase in the doses increased NPP, while NGP was not altered. Kyei-Boahen et al. (2017), evaluating the response of cowpea to inoculation and phosphate fertilization, observed that the only production component that showed differences between managements was NPP. Thus, NPP is increased under agricultural managements that provide better conditions for the crop, reducing the abortion of cowpea flowers, such as high-water availability, nutritional availability and soil with adequate physical attributes. Wong et al. (2015) suggest that in soils with low fertility, there may be lower production of reproductive structures in plants, altering physiological aspects such as the balance of phytohormones. Thus, the application of limestone helps in increasing soil fertility and, consequently, in increasing reproductive structures, having a direct effect on NPP.

The higher grain yield of the cultivar BR 17 Gurgueia, which has semi-prostrate growth habit, in comparison to BRS Guariba, semi-erect growth habit, can be explained by its high values of NPP and NGP (Table 2). It is wort pointing out that, even under rainfed conditions, with high temperatures throughout the crop development cycle and with rainfall concentrated in the vegetative stage (Figure 1), as well as in the absence of limestone application, the two cowpea cultivars obtained grain yields above the Brazilian average in the two agricultural years, which is approximately $475 \mathrm{~kg} \mathrm{ha}^{-1}$ (CONAB, 2020).

For the technological attributes, there was little variability between the factors in the two seasons, and only for the protein content the cultivar BR 17 Gurgueia had a higher value than the cultivar BRS Guariba in the first year. Thus, in addition to higher yield, the cultivar BR 17 Gurgueia tends to have higher protein content in the grains than the cultivar BRS Guariba, generating better grain quality. The values of protein content observed in the present study are similar to those reported in other studies with cowpea crop, which range from 22.0 to $23.9 \%$ (Freire Filho et al., 2011; Hamid et al., 2016). 
For cooking time, the same can be observed, since values between 6 and 23 minutes are found in the literature, with great variability for this variable according to season, cultivar and the climatic and edaphic conditions (Pereira et al., 2014; Ávila et al., 2015).

\section{Conclusions}

The cultivar BRS Guariba is more demanding in terms of soil fertility than the cultivar BR 17 Gurgueia and has inferior agronomic performance and lower grain quality. Maximum grain yields were obtained with limestone doses between 3.1 and $3.2 \mathrm{t} \mathrm{ha}^{-1}$ for the cultivar BR 17 Gurgueia and between 3.3 and $3.4 \mathrm{t} \mathrm{ha}^{-1}$ for the cultivar BRS Guariba, reaching average base saturation values of approximately 48 and $55 \%$, respectively.

\section{Compliance with Ethical Standards}

Author contributions: Conceptualization: ALGA, LBL, FBM; Data curation: ALGA, FLCM, APC; Formal analysis: ALGA, FLCM, APC; Investigation: ALGA, LBL, FBM, RMP; Methodology: ALGA, LBL, FBM, RMP; Project administration: ALGA, LBL; Resources: LBL, FBM, RMP; Supervision: LBL, RMP; Validation: ALGA, FBM; Writing - original draft: ALGA, FLCM, APC; Writing - review \& editing: LBL, FBM, RMP.

Conflict of interest: The authors declare no conflict of interest.

Funding: This work has no financial funding.

\section{Literature Cited}

Alvares, C.A.; Stape, J.L.; Sentelhas, P.C.; Gonçalves, J.L.M.; Sparovek, G. Koppen's climate classification map for Brazil. Meteorologische Zeitschrift, v.22, p.711-728, 2013. https://doi.org.10.1127/09412948/2013/0507.

Association ff Official Analytical Chemists - AOAC. Official methods of analysis of AOAC International. 16.ed. Washington: AOAC, 1995.

Ávila, B.P.; Santos, M.S.; Nicoletti, A.M.; Alves, G.D.; Elias, M.C.; Monks, J.; Gularte, M.A. Impact of different salts in soaking water on the cooking time, texture and physical parameters of cowpeas. Plant Foods for Human Nutrition, v.70, n.4, p.463-469, 2015. https://doi.org/10.1007/s11130-015-0504-7.

Bataglia, O.C.; Furlani, A.M.C.; Teixeira, J.P.F.; Furlani, P.R.; Gallo, J.R. Métodos de análise química de plantas. Campinas: IAC, 1983. 48 p.

Bortoluzzi, E.C.; Parize, G.L.; Korchagin, J.; Silva, V.R.D.; Rheinheimer, D.D.S.; Kaminski, J. Soybean root growth and crop yield in response to liming at the beginning of a no-tillage system. Revista Brasileira de Ciência do Solo, v.38, n.1, p.262-271, 2014. https:// doi.org/10.1590/S0100-06832014000100026.

Buni, A. Effects of liming acidic soils on improving soil properties and yield of haricot bean. Journal of Environmental \& Analytical Toxicology, v.5, n.1, p.1-4, 2014. https://doi.org/10.4172/21610525.1000248
Companhia Nacional de Abastecimento - Conab. Acompanhamento da safra brasileira de grãos. Safra 2019/20. Brasília: Conab, 2020. v.7, n.4, 104p. https://www.conab.gov.br/info-agro/ safras/graos/boletim-da-safra-de-graos/item/download/30348_ aa345b3df6694e420f12eedc8ffb970d. 25 Feb. 2020.

Cravo, M.S.; Smyth, T.J.; Brasil, E.C. Calagem em Latossolo Amarelo Distrófico da Amazônia e sua influência em atributos químicos do solo e na produtividade de culturas, anuais. Revista Brasileira de Ciência do Solo, v.36, n.3, p.895-907, 2012. https://doi. org/10.1590/s0100-06832012000300020.

Empresa Brasileira de Pesquisa Agropecuária - Embrapa. Sistema brasileira de classificação de solo. 3.ed. Brasília: Embrapa Solos, 2013. 353 p.

FAOSTAT. Production crops. 2020. http://www.fao.org/faostat/ en/\#data/QC. 25 Feb. 2020.

Fernandes, A.R.; Fonseca, M.R.; Braz, A.M.D.S. Produtividade de feijão caupi em função da calagem e fósforo. Revista Caatinga, v.26, n.4, p.54-62, 2013. https://periodicos.ufersa.edu.br/index php/caatinga/article/view/2770. 10 Mar. 2020.

Ferreira, D.F. Sisvar: a computer statistical analysis system. Ciência e Agrotecnologia, v.35, n.6, p.1039-1042, 2011. https://doi. org/10.1590/S1413-70542011000600001.

Freire Filho, F.R.; Ribeiro, V.Q.; Rocha, M.M.; Silva, K.J.D.; Nogueira, M.S.R.; Rodrigues, E.V. Feijão-caupi no Brasil: produção, melhoramento genético, avanços e desafios. Teresina: Embrapa Meio-Norte, 2011. 84 p. https://www.embrapa.br/busca-depublicacoes/-/publicacao/916831/feijao-caupi-no-brasil-producaomelhoramento-genetico-avancos-e-desafios. 20 Feb. 2020.

Gondwe, T.M.; Alamu, E.O.; Mdziniso, P.; Maziya-Dixon, B. Cowpea (Vigna unguiculata (L.) Walp) for food security: an evaluation of enduser traits of improved varieties in Swaziland. Scientific Reports, v.9, n.1, p.1-6, 2019. https://doi.org/10.1038/s41598-019-52360-w.

Hamid, S.; Muzaffar, S.; Wani, I.A.; Masoodi, F.A.; Bhat, M.M. Physical and cooking characteristics of two cowpea cultivars grown in temperate Indian climate. Journal of the Saudi Society of Agricultural Sciences, v.15, n.2, p.127-134, 2016. https://doi org/10.1016/j.jssas.2014.08.002.

Kyei-Boahen, S.; Savala, C.E.; Chikoye, D.; Abaidoo, R. Growth and yield responses of cowpea to inoculation and phosphorus fertilization in different environments. Frontiers in Plant Science, v.8, e646, 2017. https://doi.org/10.3389/fpls.2017.00646.

Locatelli, V.D.E.; Medeiros, R.D.D.; Smiderle, O.J.; Albuquerque, J.D.A.; Araújo, W.F.; Souza, K.T. Componentes de produção, produtividade e eficiência da irrigação do feijão-caupi no cerrado de Roraima. Revista Brasileira de Engenharia Agrícola e Ambiental, v.18, n.6, p.574-580, 2014. https://doi.org/10.1590/ S1415-43662014000600002.

Melo, F.B.; Cardoso, M.J. Cultivo de feijão-caupi. Sistemas de produção Embrapa. 2.ed. Brasília: Embrapa, 2017. 9p. https:// ainfo.cnptia.embrapa.br/digital/bitstream/item/161212/1/ SistemaProducaoCaupiCapituloSolosAdubacao.pdf. 01 Mar. 2020.

Melo, F.B.; Cardoso, M.J.; Salviano, A.A.C. Fertilidade do solo e adubação. In: Freire Filho, F.R.; Lima, J.A.A.; Ribeiro, V.Q. (Eds.). Feijão-caupi: avanços tecnológicos. Brasília, DF: Embrapa Informação Tecnológica, 2005. p.229-242. https://www.agencia. cnptia.embrapa.br/Repositorio/cap6_000fm0xytbj02wyiv80kxlb 3612vq547.pdf. 10 Feb. 2020. 
Oliveira, G.A.; Araújo, W.F.; Cruz, P.L.S.; Silva, W.L.M.D.; Ferreira, G.B. Resposta do feijão-caupi as lâminas de irrigação e as doses de fósforo no cerrado de Roraima. Revista Ciência Agronômica, v.42, n.4, p.872-882, 2011. https://doi.org/10.1590/S180666902011000400008.

Paradelo, R.; Virto, I.; Chenu, C. Net effect of liming on soil organic carbon stocks: a review. Agriculture, Ecosystems \& Environment, v.202, p.98-107, 2015. https://doi.org/10.1016/j. agee.2015.01.005.

Pereira, E.J.; Carvalho, L.M.; Dellamora-Ortiz, G.M.; Cardoso, F.S.; Carvalho, J.L.; Viana, D.S.; Freitas, S.C.; Rocha, M.M. Effects of cooking methods on the iron and zinc contents in cowpea (Vigna unguiculata) to combat nutritional deficiencies in Brazil. Food \& Nutrition Research, v.58, n.1, p.20694, 2014. https://doi. org/10.3402/fnr.v58.20694.

Raij, B.V. Fertilidade do solo e manejo de nutrientes. Piracicaba: International Plant Nutrition Institute, 2011. 420p.

Raij, B.V..; Andrade, J.C.; Cantarella, H.; Quaggio, J.A. Análise química para avaliação da fertilidade de solos tropicais. Campinas: Instituto Agronômico. 2001. 285p.

Raij, B.V.; Cantarella, H.; Quaggio, J.A.; Furlani, A.M.C. ed. Recomendações de adubação e calagem para o estado de São Paulo. 2. ed.rev.atual. Campinas: Instituto Agronômico; Fundag, 1997. 285p. (IAC. Boletim Técnico, 100).
Silva, T.R.B.; Lemos, L.B.; Crusciol, C.A.C. Produtividade e características tecnológicas de cultivares de feijão em resposta à calagem superficial em plantio direto. Bragantia, v.70, n.1, p.196205, 2011. https://doi.org/10.1590/S0006-87052011000100026.

Sokoto, A.L.; Singh, A. Yield and yield components of cowpea (Vigna unguiculata (L.) Walp.) as influenced by Sokoto phosphate rock and placement methods in the semi-arid zone of Nigeria. Nutrient cycling in agroecosystems, v.81, n.3, p.255-265, 2008. http://dx.doi.org/0.1007/s10705-007-9161-z.

Soratto, R.P.; Crusciol, C.A.C. Atributos químicos do solo decorrentes da aplicação em superfície de calcário e gesso em sistema plantio direto recém-implantado. Revista Brasileira de Ciência do Solo, v.32, n.2, p.675-688, 2008. https://doi.org/10.1590/S010006832008000200022.

Tagliaferre, C.; Santos, T.J.; Costa Santos, L.; Santos Neto, I.J.; Rocha, F.A.; De Paula, A. Características agronômicas do feijão caupi inoculado em função de lâminas de irrigação e de níveis de nitrogênio. Revista Ceres, v.60, n.2, p.242-248, 2013. https://doi. org/10.1590/S0034-737X2013000200013.

Wong, W.S.; Tan, S.N.; Ge, L.; Chen, X.; Yong, J.W.H. The importance of phytohormones and microbes in biofertilizers. In: Maheshwari, D. K. (Ed.). Bacterial metabolites in sustainable agroecosystem. Cham: Springer, 2015. p.105-158. (SDEB, volume 12). https://doi. org/10.1007/978-3-319-24654-3_6. 